\title{
Analysis of relationships between near-shore hydrodynamics and sediment movement on Osmussaar Island, western Estonia
}

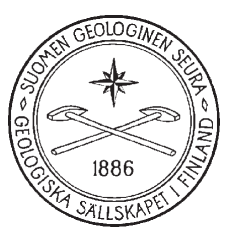

\author{
Ülo SuUrsaar $^{1)}$, Hannes Tônisson ${ }^{2 *}$, Are KOnT $^{2)}$ \\ and KaAREL ORVIKU ${ }^{2)}$ \\ 1) Estonian Marine Institute, University of Tartu, Mäealuse St. 14, Tallinn 12618, Estonia \\ 2) Institute of Ecology at Tallinn University, Uus-Sadama 5-537, Tallinn 10120, Estonia
}

\begin{abstract}
Based on field studies, hydro-meteorological data and wave hindcasts, coastal developments and their hydrodynamic forcing conditions are studied on the limestone relict island of Osmussaar. Areal growth of Osmussaar Island, which emerged from the Baltic Sea 2000-3000 years ago and has grown ever since, has practically stopped as the current global sea level rise nearly balances out the local isostatic post-glacial uplift; yet it continues on the southern shores of the island as a result of gradual accumulation of the matter eroded by waves from the north-westerly exposed Osmussaar cliff and the submarine limestone bench in front of it. Based on analysis of old maps, photographical material, and levelling surveys from coastal study sites on Osmussaar, the island as a whole is slowly migrating to the south-east. Compared to the 1960 s and 1970 s, the rate of coastal changes has increased from $0.2 \mathrm{~m}^{2} \mathrm{y}^{-1}$ to $1.2 \mathrm{~m}^{2} \mathrm{y}^{-1}$ per shoreline meter. A painted sediment experiment conducted in 2011 revealed the nearshore feeding zones for beach ridges. Storminess and high sea level events have increased on the windward, westerly exposed coast. Wave climate has undergone some cyclical changes with the last high phase in the 1990s and a new cycle probably started again 2010.
\end{abstract}

Keywords: islands, shorelines, hydrodynamics, waves, sediment transport, climate, storms, sea-level changes, Holocene, Baltic Sea, Osmussaar, Estonia

* Corresponding author email: hannest@gmail.com

Editorial handling: Joonas Virtasalo

\section{Introduction}

Although Estonia is a small country, it has a relatively long coastline and it is rich in islands. In total there are about 1500 islands, making up $4133 \mathrm{~km}^{2}$ or
$9.2 \%$ of its territory's area. Most of them comprise the West Estonian Archipelago. Located somewhat solitarily at the entrance of the Gulf of Finland, 
Osmussaar (Odensholm in Swedish) is the 14th largest island in Estonia with an area of $4.7 \mathrm{~km}^{2}$ (Fig. 1C). It is $1.3 \mathrm{~km}$ wide and $4.6 \mathrm{~km}$ long. Despite its small size, it is an island with a remarkable setting, nature and history. The island had probably already been inhabited as early as the Viking age. The continuous settlement of Estonian Swedes on Osmussaar, who thrived until World War II, goes back to at least the 14th century (Peil, 1999). Starting from the 1940s, the fate of the island was determined by its strategic position. Military actions and the coastal artillery battery shaped its landscape

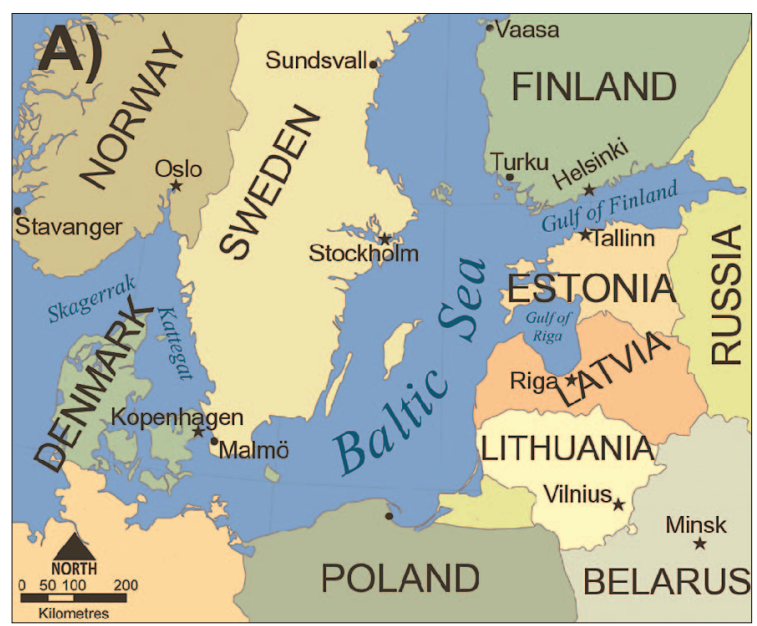

until the 1990s, when Estonia regained its independence. As a part of the West Estonian Archipelago Biosphere Reserve, it now draws the occasional tourist and is the focus of scientific research.

The geology of Osmussaar Island has been extensively studied since at least the 1920s (Öpik, 1927; see also Suuroja et al. (1999) for an overview). Less attention has been paid so far on nearshore oceanography and coastal geomorphic developments. The intriguing Neugrund Bank is located some 6$10 \mathrm{~km}$ to the NE (Fig. 1C). In the 1990s, the nearly

Fig. 1. Location map (A), map of Estonia (B) and bathymetric map of Osmussaar area (C) including RDCP moorings at Neugrund (a), Sundgrund (b); ADP mooring and painted sediment experiment (c), lighthouse $(d)$; coastal study areas "01" and "02".

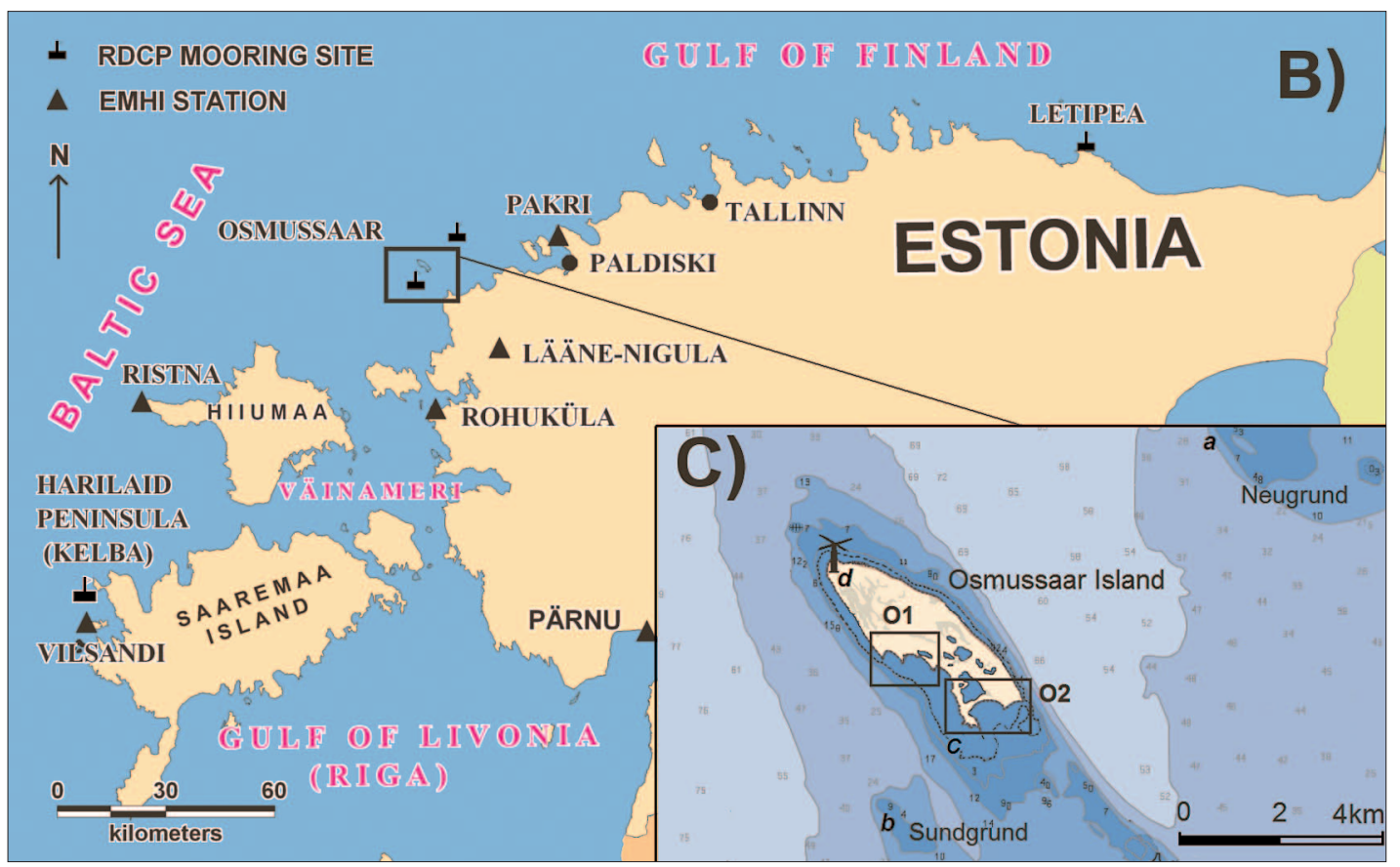


circular-shape shoal was recognised as a meteorite impact structure (Suuroja \& Suuroja, 1999; 2000). Since this discovery, the area has drawn much attention from geophysicists, marine archaeologists and biologists. The second submerged structure under study is the $8 \mathrm{~m}$ deep Sundgrund Bank, some 2-5 km SW from Osmussaar Island and $15 \mathrm{~km}$ SW from the Neugrund Bank. The shoals at both structures have been proposed as possible locations for wind farms. In order to study long-term variations in hydrodynamic forces and shallow sea geomorphic processes in the practically tideless study area (Otsmann et al., 1997), in situ hydrodynamic measurements were taken using RDCPs (Recording Doppler Current profilers) at the Neugrund structure in 2009-2010. The preliminary results were discussed by Suursaar et al. (2011). Unfortunately, the Neugrund location did not turn out very useful for analysing the long-term relationships between hydrodynamics and the coastal changes on Osmussaar then and second study site was chosen. The new results obtained at Sundgrund in 2011 are discussed in this paper.

In recent years, a number of coastal geomorphic field studies have been conducted on Osmussaar Island as well (Tônisson et al., 2012). Coastal geomorphic and landscape surveys have been regularly carried out since 2004, and various analyses have been undertaken of aerial photographs and old charts dating back to 1900 . The measurements of waves and currents taken at two sides of Osmussaar Island, i.e., on the windward western side (Sundgrund) and the leeward eastern side (Neugrund), enabled the calibration of a wave model, which was further applied to analyse longterm coastal developments on the corresponding shores of the island.

The objectives of the paper are (1) to present a natural overview of Osmussaar Island, its coasts and the surrounding seas, (2) to present local wave hindcasts for the period 1966-2011, and (3) to investigate the past, current and possible future coastal developments in relation to temporal variations in climatic and hydrodynamic forcing conditions.

\section{Study area}

\subsection{Geology and natural history of Osmussaar}

Geologically, Osmussaar is an approximately $5 \mathrm{~km}$ long relict island of the Baltic Clint, overlain by a thin (up to $2 \mathrm{~m}$ ) layer of Quaternary marine deposits. The bulk of the island is comprised of Ordovician limestone (440-480 million years old) bedrock, which is represented by its lower strata, the Öland and Viru series. The carbonate Osmussaar (Ordovician) sections are split into blocks and penetrated by breccia-like intrusions (Suuroja et al., 1999). The origin of Osmussaar Breccia has been debated for more than a century. The latest conodont datings (Mellgren et al., 2012) suggest it came from a 476 million-year-old meteorite impact, the crater of which, probably deeply buried or intensively eroded, has still not been found. Precambrian crystalline basement lies at a depth of about $170 \mathrm{~m}$ at Osmussaar.

The island emerged from the Baltic Sea about 2000-3000 years ago as a result of postglacial rebound. The study area is still experiencing the isostatic land uplift with a current rate of about 2.6 to $2.8 \mathrm{~m}^{2} \mathrm{yr}^{-1}$ (Vallner et al., 1988). This uplift rate is among the fastest in Estonia, where its influence diminishes towards the SE. On the seashores, the fast uplift mainly manifests as locally decreasing sea levels and growth of "new land".

An Ordovician limestone cliff up to $7 \mathrm{~m}$ high is the most characteristic feature on the northern part of the island (Fig. 2A). Relative to the surrounding seabed, the height of the island is 60 meters. 2-3 meter high accumulative gravel-pebble beach ridges cover the southern part. The main shore processes are erosion from the Osmussaar cliff, longshore southward transport of gravel-pebble and accumulation of material as beach ridges at the southern end of the island (Fig. 2B). Increments of the spits often rejoin the main island and several brackish-water coastal lagoons can be found behind the spits.

Although seismically stable, an earthquake of 4.7 units on the Richter scale occurred on $25^{\text {th }}$ October 1976 near Osmussaar. This was the most 


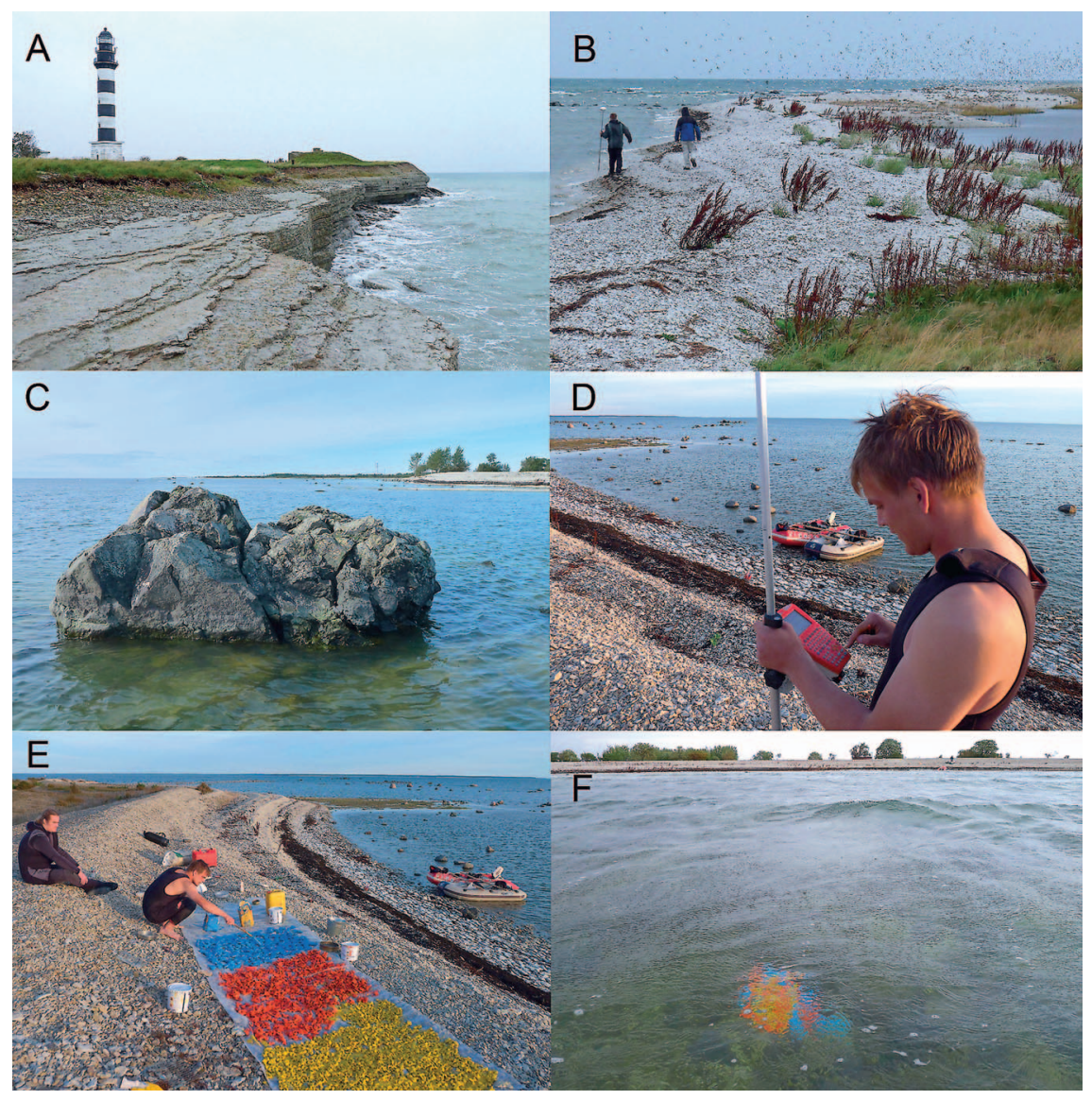

Fig. 2. Osmussaar Cliff and the lighthouse $(A)$, beach ridges in the study area 01 formed in 2005-2010 (B); Neugrund breccia near Osmussaar (C), work with DGPS (D), painting the sediment fractions $(\mathrm{E})$, the painted sediment pile nearest to the shore $(F)$. Photos by Ü.Suursaar. powerful recorded earthquake in Estonia. Its epicenter was close to Neugrund shoal, 5-7 km northeast of the island at a depth of about 10 to 13 $\mathrm{km}$. It caused the collapse of some sections of the cliff on the island's northeast coast.

\subsection{The Neugrund Structure and the Sundgrund}

The underwater coastal slope is steep on the eastern side of Osmussaar Island. The depth increases to 20 meters in less than 500 meters. However, on the western side of island the seabed is gently sloping and shallow (less than 5 meters deep) due to the limestone bench for up to $1 \mathrm{~km}$ from the shoreline (Fig. 1C). Further offshore, the depth increases rapidly. The island is exposed to storms and waves from west and north.

Also located in the Gulf of Finland about 10 $\mathrm{km}$ to the north-east from Osmussaar is the fascinating Neugrund bank. The nearly circularshaped shoal is an approximately 535 million-yearold meteorite impact structure with a rim-to-rim diameter of 7-8 km. The buried but partially reexposed (during Neogene erosion) submarine structure consists of a rim wall reaching $50 \mathrm{~m}$, the crater proper, ejecta, and a $20 \mathrm{~km}$ outer ring fault (Fig. 1D) (Suuroja \& Suuroja, 1999). The water depth at the central plateau is $1-15 \mathrm{~m}$, whereas the adjacent sea depth is $20-40 \mathrm{~m}$ shoreward and 60$70 \mathrm{~m}$ in the circular canyon-like depression to the north. Multiple shipwrecks found lying on the seabed are a testament to the unusually rugged topography of the seabed in this region.

More than a hundred isolated erratic boulders (Fig. 2C) consisting of brecciated Precambrian metamorphic rock are situated on the seabed and coasts around the structure, including on Osmussaar. In the late 1990s, the mineralogical analysis - together with geophysical mapping, 
seismoacoustic and magnetic profiling - served to demonstrate that the Neugrund Bank is a meteorite crater with an initial structural altitude of about 500 m (Suuroja \& Suuroja, 1999).

The other bank, the Sundgrund to the southwest of the island, is an ordinary shoal (Fig. 1C), where water depth is about 10 meters. Compared to the Neugrund, it is well exposed to the west, and therefore sees stronger wave activity than Neugrund does.

\section{Material and methods}

\subsection{In situ measurements of currents and waves}

The hydrodynamic study stems mainly from measurements of waves and currents using the Doppler-effect based current profiler at the banks of Neugrund and Sundgrund in the Gulf of Finland (Fig. 1B). The measurements were taken using a medium range RDCP-600 instrument manufactured by Aanderaa Data Instruments AS (AADI) on the Neugrund Bank area, $7 \mathrm{~km}$ northeast of Osmussaar $\left(59^{\circ} 20^{\prime} \mathrm{N}\right.$; $\left.23^{\circ} 30^{\prime} \mathrm{E}\right)$ between $20^{\text {th }}$ November 2009 and 24 ${ }^{\text {th }}$ April 2010. The instrument (Fig. 3C) was installed on the seabed at a depth of approximately $15 \mathrm{~m}$. Over 155 days the instrument recorded hourly data on currents at seven depth layers, wave parameters, sea level variations and water column properties, such as water temperature, salinity and turbidity (see also: Suursaar et al., 2011).

The Sundgrund measurements were performed using the same instrument at Sundgrund Bank, 3 $\mathrm{km}$ south of Osmussaar $\left(59^{\circ} 15^{\prime} \mathrm{N} ; 23^{\circ} 24^{\prime} \mathrm{E}\right)$ at a depth of $11 \mathrm{~m}$ between $18^{\text {th }}$ September and $10^{\text {th }}$ November 2011. Simultaneously, a few additional measurements were taken at Sundgrund using a short range $3 \mathrm{MHz}$ ADP (manufactured by YSI/ Sontek) between $18^{\text {th }}$ and $20^{\text {th }}$ September 2011, as were other related geomorphic investigations, including the painted sediment experiment. For sampling the nearshore hydrodynamics, the instrument was deployed approximately $0.5 \mathrm{~km}$ from Osmussaar at a depth of $2 \mathrm{~m}$. With a $20 \mathrm{~cm}$ sampling cell size, the velocity profiles started just $0.6 \mathrm{~m}$ from the seabed.

\subsection{Meteorological and sea level data}

In order to provide meteorological forcing for the wave model, as well as background information for coastal studies, the meteorological and sea level data from some weather and tide gauge stations, which are operated by the Estonian Meteorological and Hydrological Institute (EMHI), were used.

Wave model forcing was obtained from the Pakri (Paldiski) meteorological station $\left(59^{\circ} 23.3^{\prime} \mathrm{N}\right.$; $\left.24^{\circ} 02.4^{\prime} \mathrm{E}\right)$, located $30 \mathrm{~km}$ east of the Neugrund mooring site and $38 \mathrm{~km}$ from the Sundgrund site. The Pakri station has been operational since 1865, but the exact position of the station on the Pakri Peninsula has changed slightly, most recently in September 2003. As the long-term wind input data from the closest coastal meteorological station (i.e. Pakri) could not be considered homogeneous (Keevallik \& Soomere, 2009), the data from the slightly more distant Lääne-Nigula station was used as well (Fig. 1). It is $37 \mathrm{~km}$ from the Sundgrund and $43 \mathrm{~km}$ from the Neugrund. Although the station $\left(58^{\circ} 57.1^{\prime} \mathrm{N} ; 23^{\circ} 48.9^{\prime} \mathrm{E}\right)$ is located some 20 $\mathrm{km}$ inland, the landscape is flat and there are no prominent obstacles surrounding the wind instrument. Hence, the data series are quite homogeneous (Jaagus \& Kull, 2011). Digitized wind records at both stations are available since 1966 . Winds were measured by "weathercocks" (wind vanes of Wild's design) during 1966-1976; automatic anemorhumbographs during 1976-2003; and MILOS-520 automatic weather stations since September 2003.

Sea level data were obtained from three tide gauges located close to Osmussaar Island (Fig. 1): Paldiski $(37 \mathrm{~km})$, Rohuküla $(40 \mathrm{~km})$ and Ristna $(80 \mathrm{~km})$. Digitized data has been available since 1950. Annual average and maximum relative sea level were used in the study. The data represent the relative sea level with regard to the Baltic Sea Height System (or Kronstadt datum). The Kronstadt zero was defined as the average sea level of that gauge in $1825-1840$, and it approximates $( \pm 2 \mathrm{~cm})$ the present 
mean sea level of Estonian tide gauges (Suursaar \& Sooäär, 2007). For interpreting the long-term changes in local relative sea level, local land uplift rates were taken from the Estonian and Scandinavian isostatic uplift maps (e.g. Vallner et al., 1988; Lambeck et al., 1998).

\subsection{Wave modelling}

A set of wave hindcasts was performed using a semiempirical SMB-type wave model. The SMB-model, also known as the significant wave method, is based on the fetch-dependent shallow-water equations by Sverdrup, Munk, and Bretschneider, further modified in the Shore Protection Manuals of the U.S. Army Corps of Engineers (e.g. USACE, 1984). Based on wind data, the model calculates the significant wave height ( $\mathrm{Hs})$, wave period and wavelength for a designated location. As the role of remotely generated waves (swell) is small and the memory time of the wave fields in the Baltic Sea is fairly short (Soomere et al., 2008), this relatively simple method can deliver reasonably good and fast results for limited area long-term hindcasts (Suursaar, 2010; 2013; Suursaar et al., 2012) in cases where the gridded geostrophic wind data required for 3rd generation wave models are not available in the desired resolution or length.

Firstly, the wind data from the Pakri station were used to run the wave model, and the wave data obtained by the RDCP at Neugrund served to calibrate the model (Fig. 3A). Our idea was to calibrate the wave model using high-quality wave measurements, so that afterwards the model can act as a virtual extension of the fixed-point applications both for hindcasts and forecasts. We admit that in doing so, the exact model version did not necessarily have to be the one we used for hindcasts. Instead, the site-dependent calibration procedure became important for the model set-up. Although the calibration also includes a search for the appropriate depth and a certain correction factor could be applied uniformly for wind speeds at a specific location, the most important item was prescribing the fetch for different sectors, which was performed with a step of $20^{\circ}$.
After measuring the fetches from nautical charts for the Neugrund location, the comparison statistics between the measured and modelled hourly time series showed that the series were not close enough yet. The fetch is usually measured as the headwind distance from the nearest shore for the applicable wind direction, and a procedure for taking into account basin properties in a wider wind sector is applied (Massel, 2010). In practice, it was difficult to guess the exact influence of islands, shoals and coastline on waves. But calibration gave us some important feedback. Also, the wind forcing is usually far from ideal, which should mean "open terrain" or full openness to every direction. A new fetch distribution was created by maximizing the correlation coefficient and minimizing the root mean square error (RMSE) by consecutively adjusting the fetch in all $20^{\circ}$ wide sectors. In our case, the calibration was done iteratively by keeping the maximum and average wave heights equal in the modelled and reference series. In fact, the procedure modified slightly the "real" geographical fetches in order to compensate for the wind speed impediment of certain wind directions. For example, Pakri wind data projected at the Neugrund location required enhancement of wind speed (i.e. fetch) for SSW direction. The direction was somewhat shaded by local vegetation and buildings at Pakri meteorological station, but had actual fetches of up to $30 \mathrm{~km}$ at Neugrund and yielded up to $200 \mathrm{~km}$ long manipulated fetches. On the other hand, fetch from Pakri's exposed NNW side was reduced to $20 \mathrm{~km}$ as a result of the influence of Neugrund's shoals on the RDCP data. See Suursaar (2013) for full details of the calibration procedures at different locations. For the hourly-based 40-day calibration period (Fig. $3 \mathrm{~A}$ ), we finally obtained a correlation coefficient of 0.81 and an RMSE of $0.227 \mathrm{~m}$ (relative RMSE=11 $\%$ ). The site-dependent calibrated model was then used in a multi-year wave hindcast at $1 \mathrm{~h}$ interval, as it would have been measured by the same RDCP at the same location.

The calibration quality at Neugrund was somewhat lower than in our previous efforts near Harilaid-Vilsandi ( $r=0.88$, RMSE $=0.23$ m, $7.4 \%$ ) (Suursaar \& Kullas, 2009) and Kunda-Letipea 

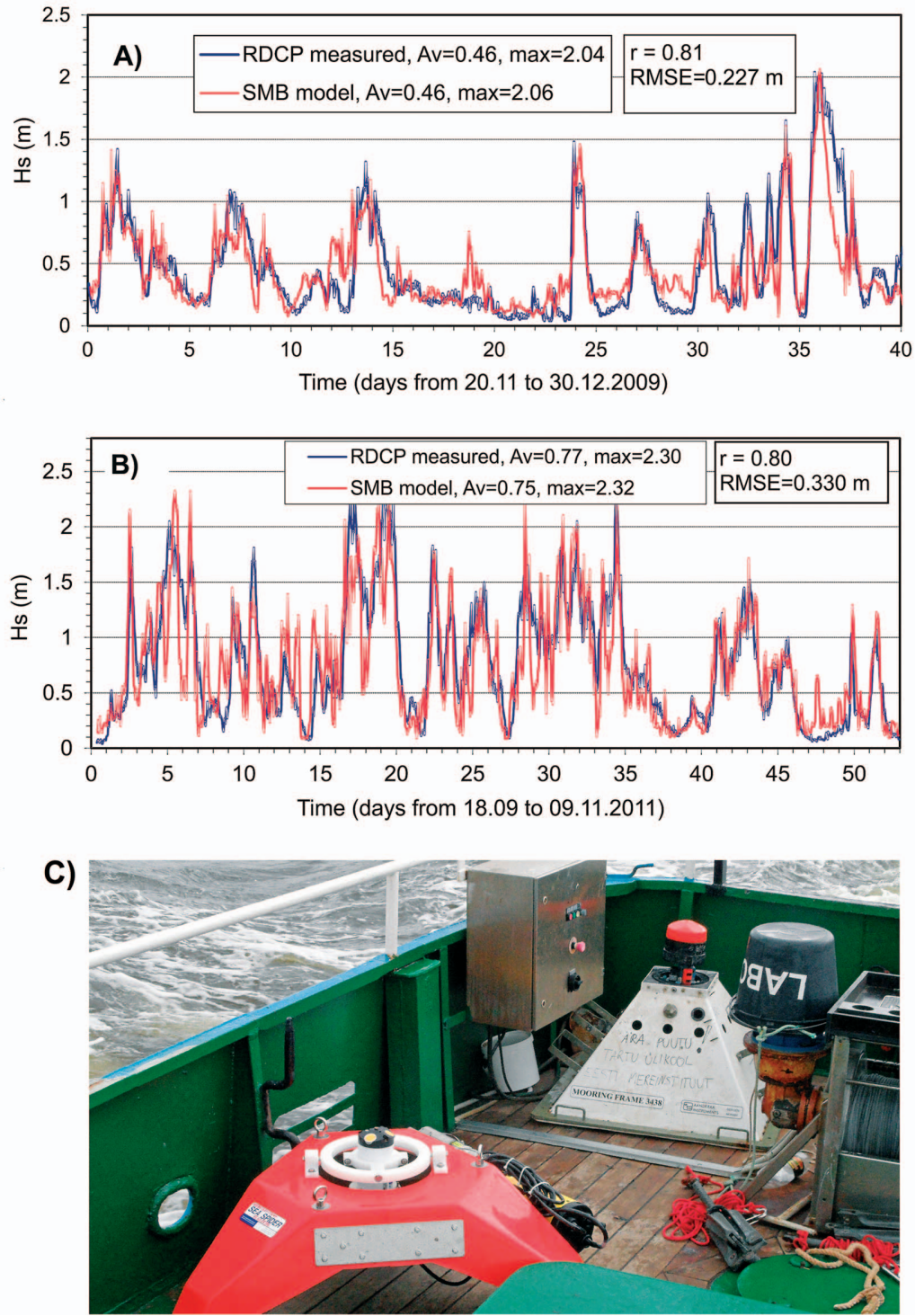

Fig.3. Comparison (calibration) between the wave model reaults and the measurements: Neugrund significant wave hights computed with Pakri wind forcing (A); Sundgrund waves simulated using Lääne-Nigula wind forcing (B). The wave measurement instruments RDCP (attached to the white frame) and ADP (with red Sea-Spider frame) on the deck of a research vessel (C; photo by Ü.Suursaar). shallow water effects. Also, according to Keevallik \& Soomere (2009), the Pakri station offers somewhat mixed results regarding openness and marine wind properties. The influence of the North Estonian Clint (limestone cliff) may be one reason for that. Unfortunately, the position of the station on the Pakri peninsula has changed three times, most recently in September 2003. Hence, only hindcasts from 2003 to 2011 should be considered as representative (Suursaar et al., 2011).

The results of calibration between the Sundgrund wave measurements and the waves modelled using LääneNigula wind forcing is presented in Fig. 3B. The comparison results were reasonably good. The correlation coefficient between the raw, hourly data over the 52 days period was 0.80 . The relatively high RMSE $(0.33 \mathrm{~m})$ appeared only due to high wave variability in stormy conditions in 2011 (compare Fig. 3A and 3B). The average $(0.77 \mathrm{~m}$ measured and 0.75 $\mathrm{m}$ modelled) and maximum (2.30 measured, $2.32 \mathrm{~m}$ modelled) wave heights obtained were very close. Standard deviations barely differed (0.53 m measured, $0.51 \mathrm{~m}$ modelled) as well. And differently from PakriNeugrund, the long coverage of the Lääne-Nigula wind forcing data allowed us to construct the 19662011 wave hindcast for Sundgrund. $(\mathrm{r}=0.92$, RMSE $=0.22 \mathrm{~m}, 7.8 \%$ ) (Suursaar, 2010; 2013), largely due to the greater distance (about 30 $\mathrm{km}$ ) between the wind measurement sites at Pakri and the wave hindcast sites at Neugrund. The modelling result was also less accurate due to the influence of the rugged seabed in the area, as the simple wind-wave fields may occasionally be "contaminated" by refraction, breaking and other

\subsection{Coastline studies}

Studies on recent coastal geomorphic changes can benefit greatly when old maps and aerial photographs are available (see e.g. Tónisson et al., 2008; 2011; 2012). At the Osmussaar study sites, topographic maps from the years 1900, 1935, 1939, 1947, 1961 and 1981; aerial photographs from 1987; and 
orthophotographs from 1998, 2005, 2008 and 2010 (pixel sizes between 25 and $100 \mathrm{~cm}$ ), were compared to analyse the changes in shoreline position. Old maps were scanned and analysed using MapInfo software. Although maps even in the same scale differed in accuracy, individual topographic features (buildings, crossroads etc.) easily discernible both on maps and on site, assisted in calibrating them.

The main study areas were in the western tip of the island (the location of former harbour, near the lighthouse, Figs. 1C \& $2 \mathrm{~A}$ ) and at the south-western part of the island (areas "O1" and "O2", Fig. 1C). GPS measurements and precise levelling studies were performed in 2004-2012 to assess short-term changes in shoreline position and the contours of beach ridges. From 2004 until 2010, shoreline positions were measured using hand-held Garmin devices (accurate to within $3 \mathrm{~m}$ ), and after 2010, shoreline positions were measured using a Leica DGPS GS09, accurate to within 1-2 cm (Fig. 2D). The rate of coastal change was calculated as a ratio of the sum of volume of erosion and accumulation to the duration of the measured period. The results are given as an average per one shoreline meter.

A levelling survey was carried out to evaluate changes in volumes of coastal features using a Leica Sprinter Digital Level 180M. The Leica DGPS GS09 has been used to increase the quality and speed of measuring profiles since September 2011. Levelled profiles, measured in July 1972 (by Dr Kaarel Orviku), were also analysed in the current study. Their locations in 1972 were recorded on hand-drawn charts and described by using some reference objects (big rocks, poles, roads), azimuths and distances from each-other. We might assume that the alongshore accuracy of those old profiles should be 3-6 meters. Cross-shore deviations are much smaller due to the possibility of using older beach ridges as fixed objects. It is not fully correct to analyse the exact changes in profiles during those 40 years. However, it is still possible to compare the maximum heights and number of clearly visible beach ridges close to the shoreline. MapInfo software was used to calculate reductions in the erosion areas and increases in accumulative areas.

\subsection{Painted sediment experiment}

Already in the 1970s, some field tests were carried out by K. Orviku and his colleagues to determine the origin of accumulative material in the beach ridges and the sediment flow directions both in the Black Sea and in the Baltic Sea (Orviku, 1979). Resources for such tests during the Soviet times were much greater than now and huge amounts of painted sediments were placed at several depths. However, at that time it was not possible to relate the results of those studies with hydrodynamic parameters and exact changes on the shores. Moreover, access to the coast and coastal sea was limited due to the strict border regime and therefore the studies were sporadic. Often, when revisited, the painted sediments had all already disappeared into bigger beach ridges.

To locate sediment transport zones, a more sophisticated analysis of painted sediments was carried out at part of the current study. Collected locally from the beach ridges, sorted particles with the following diameters were used (Figs. 2E \& F): $1-2.5 \mathrm{~cm}$ (yellow), $2.5-5 \mathrm{~cm}$ (red) and 5-10 cm (blue). Non-fluorescent, water and wear resistant, asphalt paints were used. The painted sediments were accumulated in piles and placed in $0.5-4 \mathrm{~m}$ $(0.5 ; 1 ; 1.5 ; 2 ; 2.5 ; 3$ and $4 \mathrm{~m})$ depths on the limestone bench in September 2011. The locations were recorded with Real Time Kinematic GPS (RTK-GPS) and were photographed. The study sites were revisited after an autumn storm in November 2011 and again in November 2012, and the changes were registered.

\section{Results and discussion}

\subsection{Hydrodynamic conditions around Osmussaar in 2010-2012}

During the 155 day measurement period at Neugrund, the maximum wave height of $3.1 \mathrm{~m}$ was attained on 20 February 2010 with a sustained wind speed of $12.6 \mathrm{~m} \mathrm{~s}^{-1}$. However, the average wind speed did not exceed $13.2 \mathrm{~m} \mathrm{~s}^{-1}$ (with $21 \mathrm{~m} \mathrm{~s}^{-1}$ gusts) at any time during the measuring period. As a result 
of meteorologically induced sea level variations, the depth of the instrument varied between 13.9 and $15.2 \mathrm{~m}$ over the 155 days. The average measured sub-surface current velocity was $9.8 \mathrm{~cm} \mathrm{~s}^{-1}$, and the maximum current speed reached $36 \mathrm{~cm} \mathrm{~s}^{-1}$.

Over the 52 day measurement period at Sundgrund, the maximum wave height reached 3.5 $\mathrm{m}$ and the maximum sub-surface current speed reached $49 \mathrm{~cm} \mathrm{~s}^{-1}$ at the one-hour sustained wind speeds of up to $13.1 \mathrm{~m} \mathrm{~s}^{-1}$ (Fig. 4A). At both study sites, the wave parameters were fetch-dominated. The coastal sea currents 3-7 km offshore were mostly driven by wind and modified by coastline and sea bottom topography. No wave driven or swash-generated coastal zone currents were measured or calculated in this study.

Based on wind speed data from the Pakri station, the wind speed increased from 2-3 $\mathrm{m} \mathrm{s}^{-1}$ to $8-10 \mathrm{~m}$
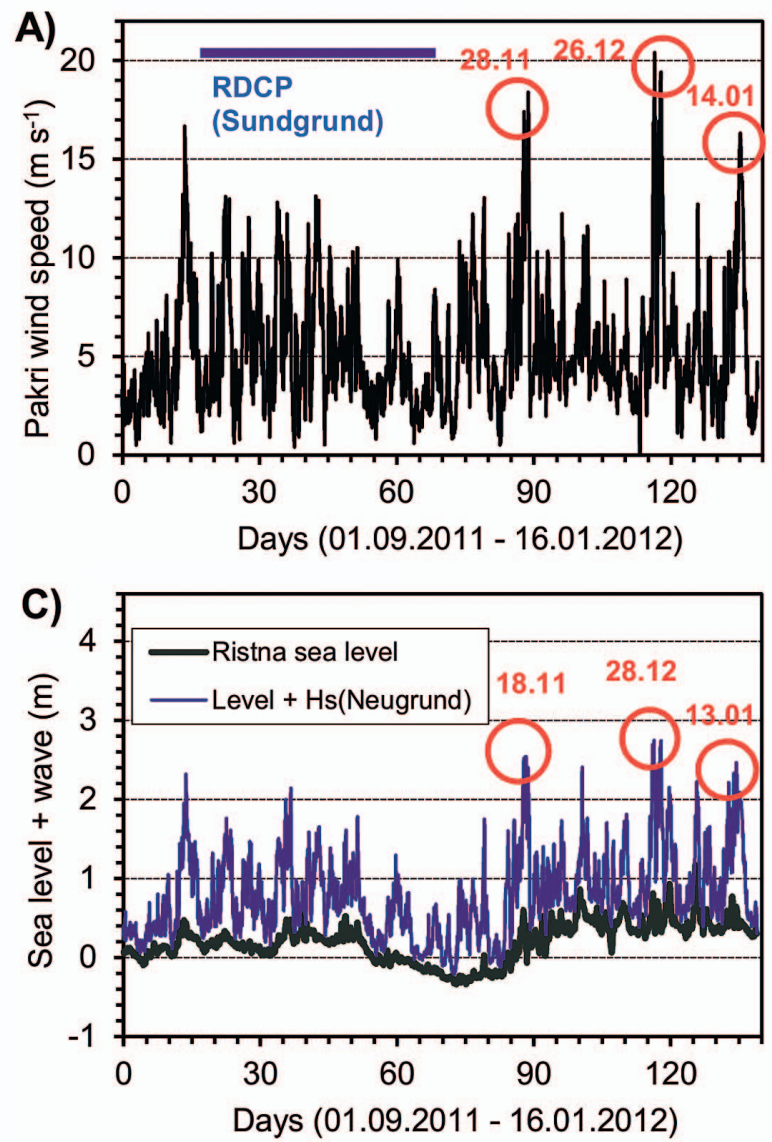

$\mathrm{s}^{-1}$ over the period of 45 hours of the parallel (both RDCP and ADP-based) hydrodynamic study (Fig. 5). The wave height also grew, but more at the deeper location. During calm wind conditions, the $(\mathrm{Hs})$ wave heights were rather comparable both in the shallow ( $2 \mathrm{~m}$ deep) nearshore location and in the deeper $(11 \mathrm{~m})$ Sundgrund shoal (Fig. 5B). Apart from the wave breaking zone, the high wave activity is physically not possible in the shallow sea. There were no uniformly established wave directions (hours 0-7; Fig. 5A), when the weak easterly wind was partly shaded by the land. Mixed waves approached the measuring site from different angles, including the part that possibly diffracted or refracted behind Osmussaar Island. However, the wave direction settled to $S W$ as wind speed increased and land shade disappeared (Fig. 5). The calm to moderate stormy conditions that prevailed during
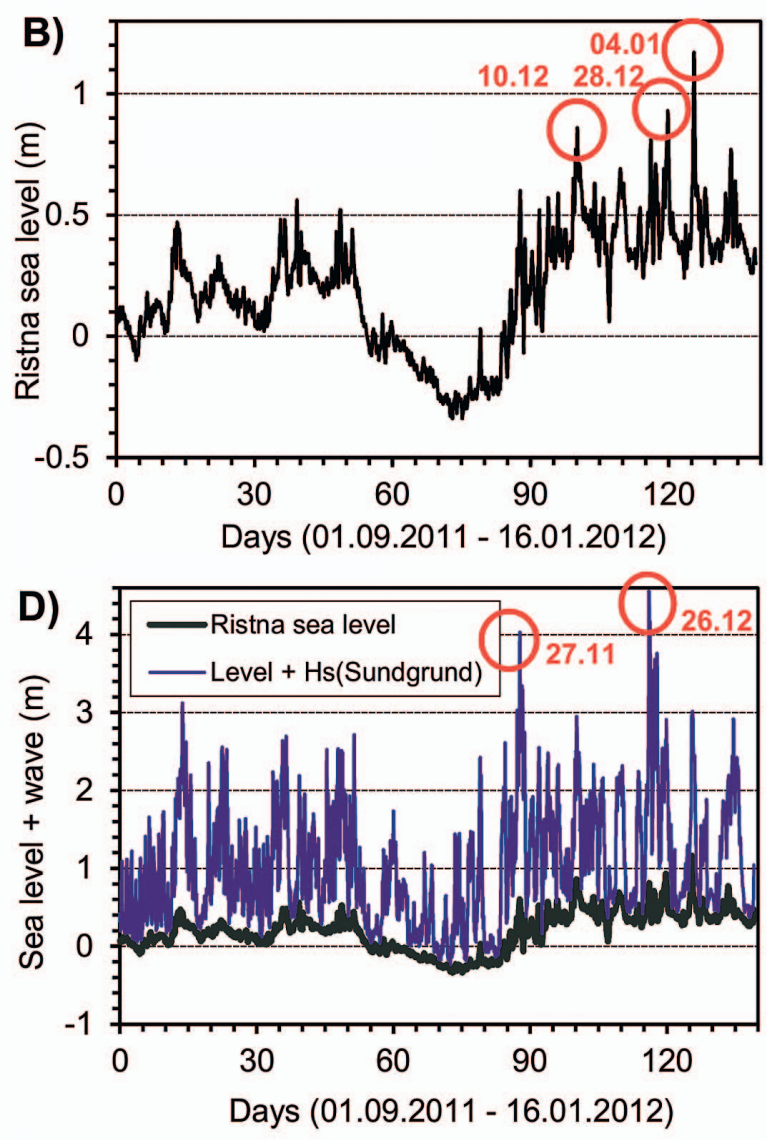

Fig. 4. Time series of Pakri wind speeds (A), Ristna tide gauge sea levels (B), combined Ristna sea level and modelled Neugrund waves (C), and Ristna sea level with modelled Sundgrund waves (D) during the stormy season $2011 / 2012$. 

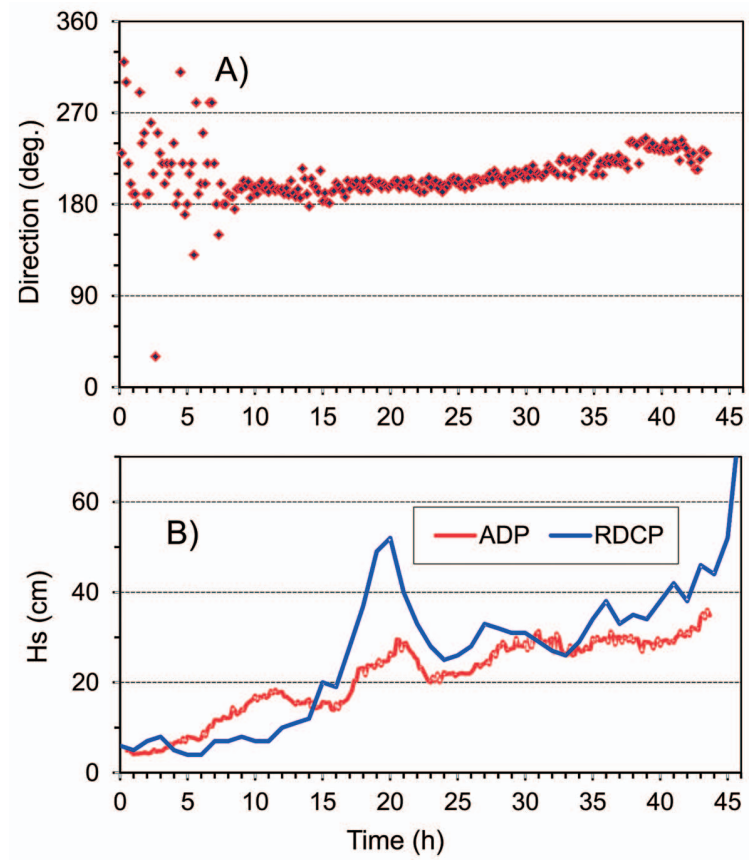

Fig. 5. Wave directions measured by ADP at the study site $01(A)$; comparison of significant wave heights between hourly measured RDCP outputs with the shallow sea ADP wave data measured with 10 min interval (B). Time scale begins on 18 September 2011; 1200 UTC.
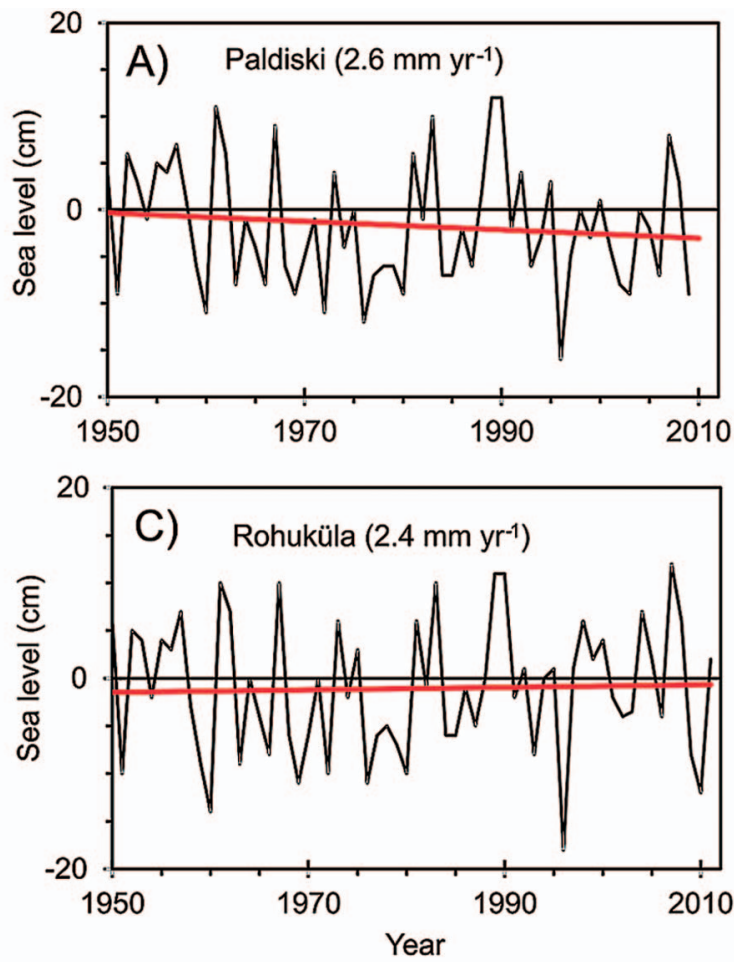

our field studies (Fig. 4) are geomorphically not potent enough and one must seek for strong storms from hindcasts.

\subsection{Long-term tendencies in local forcing conditions}

Based on hydrodynamic measurements and the semi-empirical wave hindcasts, it was found that the main hydrodynamic forces acting upon both banks and on their adjacent seashores were waves and occasional strong storm surges (e.g. Suursaar et al., 2008; Orviku et al., 2009), which have the capacity to elevate the sea level up to $2-3 \mathrm{~m}$ above the mean sea level. Such strong storm surges have occurred randomly, e.g. on 1967, 2001 and 2005 (Suursaar et al., 2006; Tônisson et al., 2008).

It is interesting that, while the local mean sea level is still decreasing in most tide gauges around Osmussaar (Fig. 6), this relatively slight decrease ranging between zero and $1.1 \mathrm{~mm} \mathrm{yr}^{-1}$ is statistically insignificant. Obviously, the regional postglacial
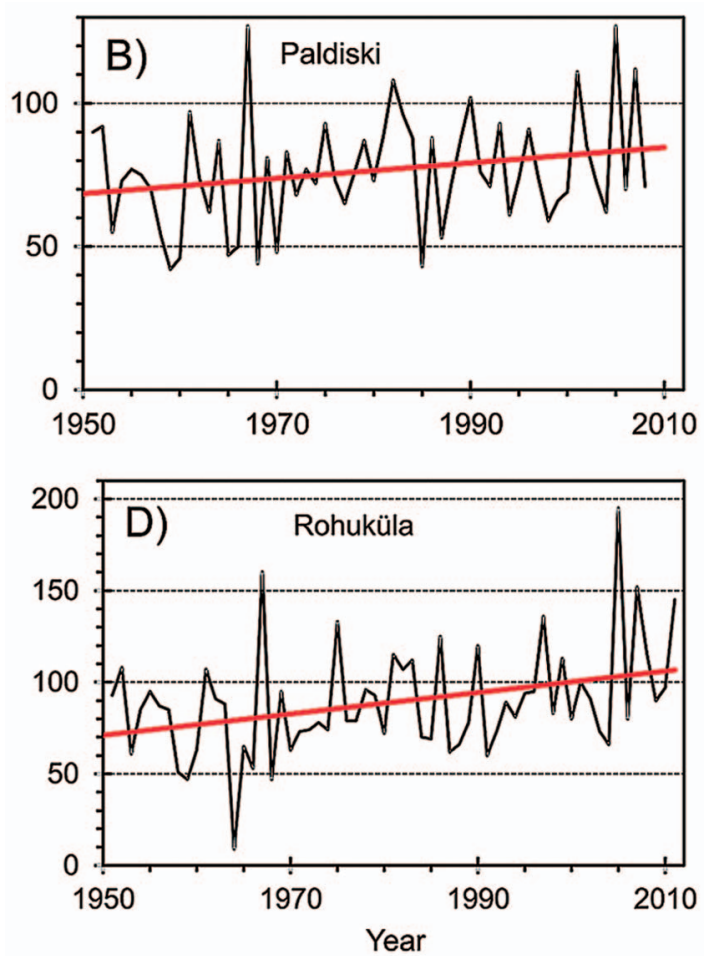

Fig. 6. Variations in annual mean (A,B) and maximum (C,D) sea levels at two tide gauges closest to the Osmussaar in 1950-2011. The numbers in brackets denote approximate post-glacial land uplift rates. 
uplift $\left(2.6 \mathrm{~mm} \mathrm{yr}^{-1}\right)$ is already roughly balanced out by the global sea level rise. While the area of Osmussaar has steadily grown since appearing above the sea surface, it has basically stopped by now and the areal growth occurs mainly in the accumulative southern parts of the island. The global rise was probably around $1 \mathrm{~mm} \mathrm{yr}^{-1}$ in the 19 th century (Ekman, 1999), but has accelerated up to 1.7 or even $2 \mathrm{~mm} \mathrm{yr}^{-1}$ by the second half of the 20th century (Johansson et al., 2001; Church \& White, 2006). However, the most recent estimates based on satellite altimetry tend to yield even higher values, e.g. up to $3.2 \mathrm{~mm} \mathrm{yr}^{-1}$ for a short period 19932009 (Church \& White, 2011).

Both in Estonia (Suursaar \& Sooäär, 2007) and in other Baltic states (Dailidiene et al., 2006), the majority of overall increases in sea level have been observed during the coldest half of the year (November-March). The second important outcome of Fig. 6 is that, despite land uplift, the annual maximum sea levels are increasing fast (up to $7 \mathrm{~mm} \mathrm{yr}^{-1}$ ) in all the tide gauges. These two regional peculiarities can be explained by the increase in local storminess and in the frequency of westerly winds along the windward coasts of West Estonia that occur in the coldest half of the year (Jaagus et al., 2008; Suursaar, 2010).

Waves at Sundgrund are typically higher than at Neugrund (Figs. 4C \& D). Based on Sundgrund hindcasts presented in this study (Fig. 7) and the Neugrund updates (Figs. $4 \& 8$ ), wave activity is higher on the western coast of Osmussaar $(\mathrm{Av}=0.7$ $\mathrm{m}$, annual maxima in terms of $\mathrm{Hs}$ around $4 \mathrm{~m}$, with a real maxima probably up to $6-7 \mathrm{~m}$ ), as fetch lengths reach up to $400-500 \mathrm{~km}$ in the western directions. Seas are calmer on the northern side of the island, where maximum fetch lengths are just $100-200 \mathrm{~km}$ and the maximum expected wind speeds for these (northerly) directions are less than for westerlies. For instance, at Neugrund the average (in terms of $\mathrm{Hs}$ ) wave height during the most reliable hindcast period from September 2003 to April 2010 was $0.4 \mathrm{~m}$ (Fig. 8) and maxima attained was $3.2 \mathrm{~m}$. Wave statistics suggest the corresponding absolute maximum height of single waves would have been about $5 \mathrm{~m}$. Both the average wave heights and higher
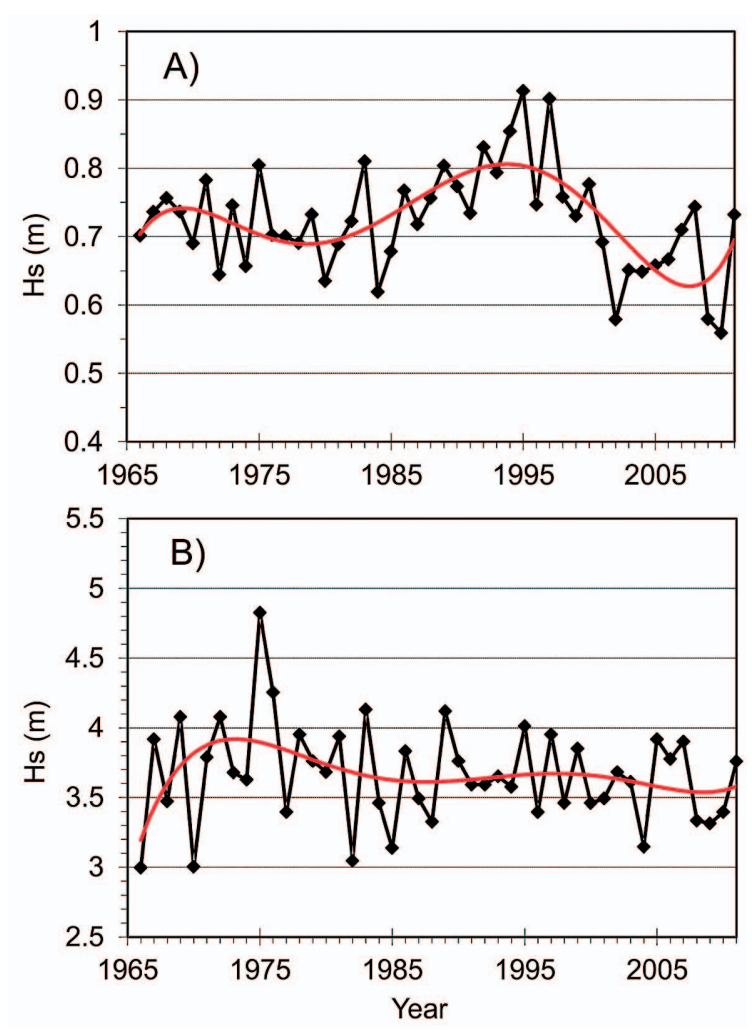

Fig. 7. Long-term (1966-2011) hindcast results of wave conditions on Sundgrund, Osmussaar west coast; annual averages $(A)$ and annual maxima $(B)$.

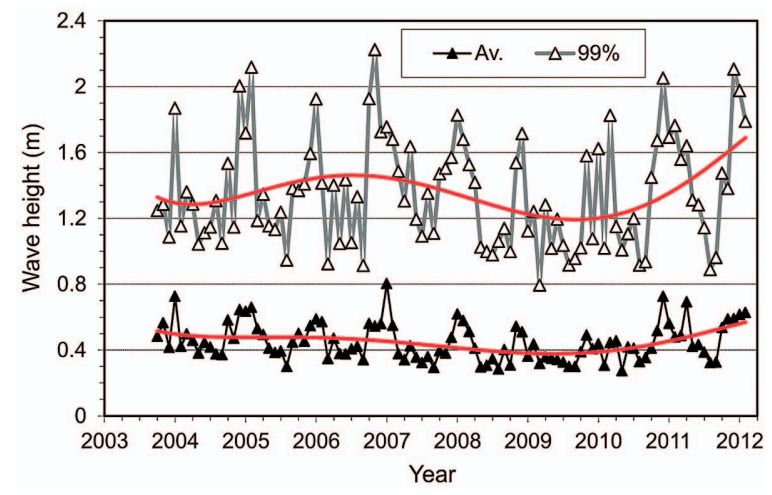

Fig. 8. Average (Av.) and 99\% wave heights (in terms of $\mathrm{Hs}$ ) computed on monthly basis from September 2003 to February 2012 at Neugrund (during the homogeneous data cut of Pakri wind forcing). 
percentiles showed seasonal variations (Fig. 8) confirming that rough seas in the Baltic Sea prevail in autumn and winter, and calm conditions are more likely in spring and summer (Zaitseva-Pärnaste et al., 2009; Suursaar, 2013).

Affecting the western coast of Osmussaar Island, the prominent wave events probably took place in 1975 and 1976. Other wave-storms occurred in 1983, 1989, and 1995, and more recently in 2005 and 2007 (Fig. 7). Our previous wave hindcasts suggest that maximum wave heights have increased along the westerly exposed coasts of Estonia (e.g. Suursaar, 2010; Suursaar et al., 2012), presumably including the Sundgrund Bank, but decreased at the northerly exposed coasts, including the Neugrund Bank. While average wave conditions at Sundgrund show some cycles and a slightly decreasing trend (Fig. 7A), the trend in maxima is not increasing either. However, the hindcast results between 1966-1976 should be considered less reliable, as some instrument changes occurred in 1976.

\subsection{Changes in shoreline and beach profiles in relation to changes in forcing conditions}

On the basis of archived descriptions and an analysis of the locations of old lighthouse ruins at the northern tip of the island it was established that the Osmussaar cliff (Fig. 2A) is slowly retreating at an average rate of $9 \mathrm{~cm} \mathrm{yr}^{-1}$. The 7 $\mathrm{m}$ high limestone scarp is a relatively strong obstacle for waves and the retreat rate may seem slow, just about 15 meters within last 160 years, but the amount of sediments eroded from the cliff is around $0.5 \mathrm{~m}^{3}$ per one meter of shoreline each year. Most of the erosion appears at the cliff's foot which results in large blocks the diameter of several meters falling into the sea. This material in turn protects the cliff from erosion for several decades until it is eroded too. After that, waves can attack the foot of the cliff again and the same process repeats.

Osmussaar as a whole is slowly migrating to the south-east, as the coastline is migrating seaward in the south-west and southern part as a result of the formation of accumulative beach ridges and spits (Fig. 9). The land is considerably lower, and therefore the areal changes are faster there. The spit in the southern part of the island has gradually grown to the south-eastward direction in the last century. The former small bay (Inhamne) became a lake when another spit-like formation closed the entrance into the bay between 1900 and 1935 (Fig. 9). In addition, the southern coast of the island has migrated over 120 meters southward.

As with the other coasts studied in Estonia (Suursaar et al., 2008; Tônisson et al., 2008; 2011) the most rapid changes in Osmussaar have occurred either during exceptionally strong storms or in periods of increased cyclonic and wave activity, the last high phase of which occurred in the 1980s and 1990s (Fig. 7A). Map analyses indicate that the processes were twice as rapid during the period between 1982-1998 than in other periods. The rate of coastal change increased from $0.2 \mathrm{~m}^{2}$ year ${ }^{-1}$ to

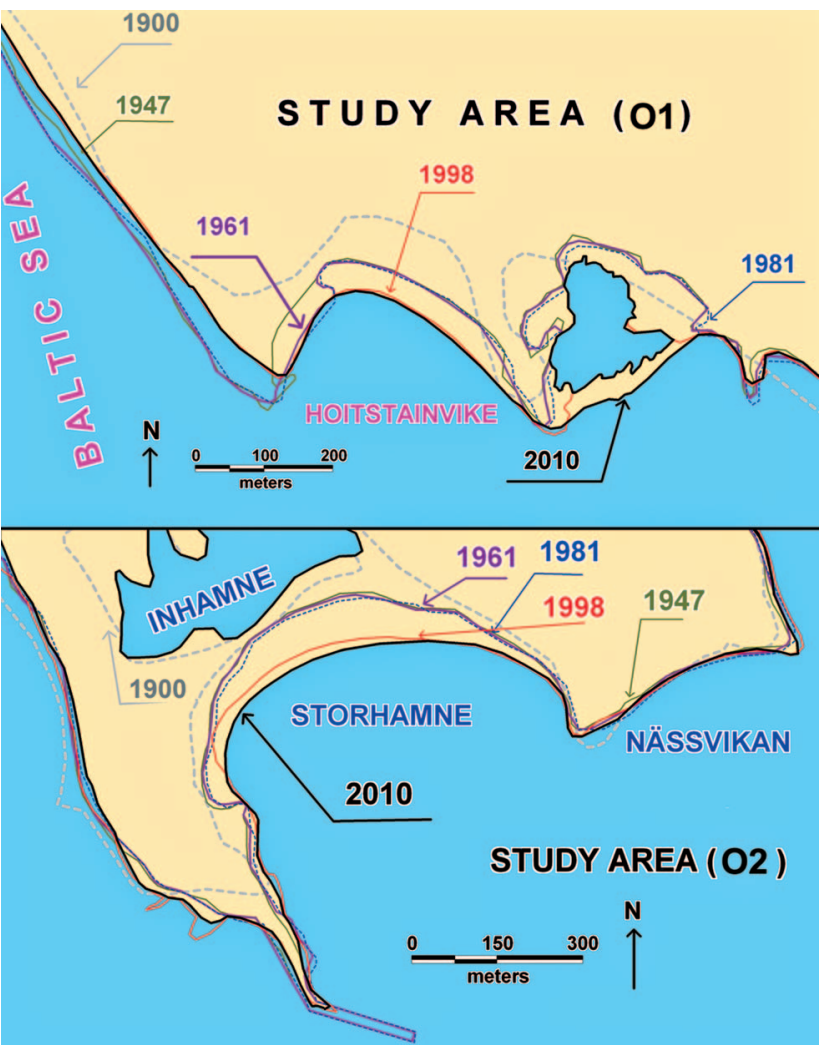

Fig. 9. Shoreline changes at the coastal study areas 01 and 02 (see also Fig. 1). 
nearly $1.2 \mathrm{~m}^{2}$ year ${ }^{-1}$ for each meter of shoreline compared to the previous period (1960-1980). Since the beginning of the 1980 s, extensive erosion occurred even in the former transport zone. The rate of shore changes has somewhat decreased during the last decade. However, it still exceeds twice the volume of changes measured before the 1980s. Moreover, the share of erosion has reached over $1 / 3$ of total changes (Fig. 10).

There is a clear relationship between the standardized $\mathrm{Hs}^{2}$ (average $=1$ ) and coastal processes (i.e., wave energy is proportional to the wave height squared). Maximum values of $\mathrm{Hs}^{2}$ appeared also in the same period as the most rapid shore changes (1982-1998, average 1.2), and have decreased by about one third (to 0.86) for the last period. The period 1962-1981 is a little more difficult to interpret. The wave hindcast starts from 1966 while the map to analyse the coastal changes was compiled in 1962 . However, the relatively high $\mathrm{Hs}^{2}(0.96)$ is well correlated with the fact that the share of erosion on the westerly exposed study area ("O1") reached over the half of total changes in that period. Also, temporal variations in magnitudes of shore changes (erosion+accumulation) are rather synchronous at both study areas (Fig. 10). Besides the within-thearea changes, erosion in $\mathrm{O} 1$ area partly contribute to accumulation in $\mathrm{O} 2$ area, as westerly stormwinds prevail at Osmussaar. On the other hand, erosion in $\mathrm{O} 2$ does not contribute to accumulation in $\mathrm{O} 1$, as the hydrodynamic forces associated with southerly or easterly winds are relatively weak.

The results of the levelling surveys confirm the findings described above. Some of the profiles (No. $6,7,8,10,11$; Fig. 11) were already measured in 1972. On profile 8 , the shoreline has receded nearly 10 meters as a result of erosion on the western coast, which is exposed to the Baltic Proper, and the shoreline has advanced 10 meters seaward on the eastern coast as a result of accumulation. The sediments eroded from the western part of the island have probably travelled around the SW tip of the island and accumulated on the coast of Storhamne Bay. Less than 5 meters of erosion is also visible on profiles no. 6 and 7. Much higher beach ridges (over 3 meters compared to approximately 2 meter high
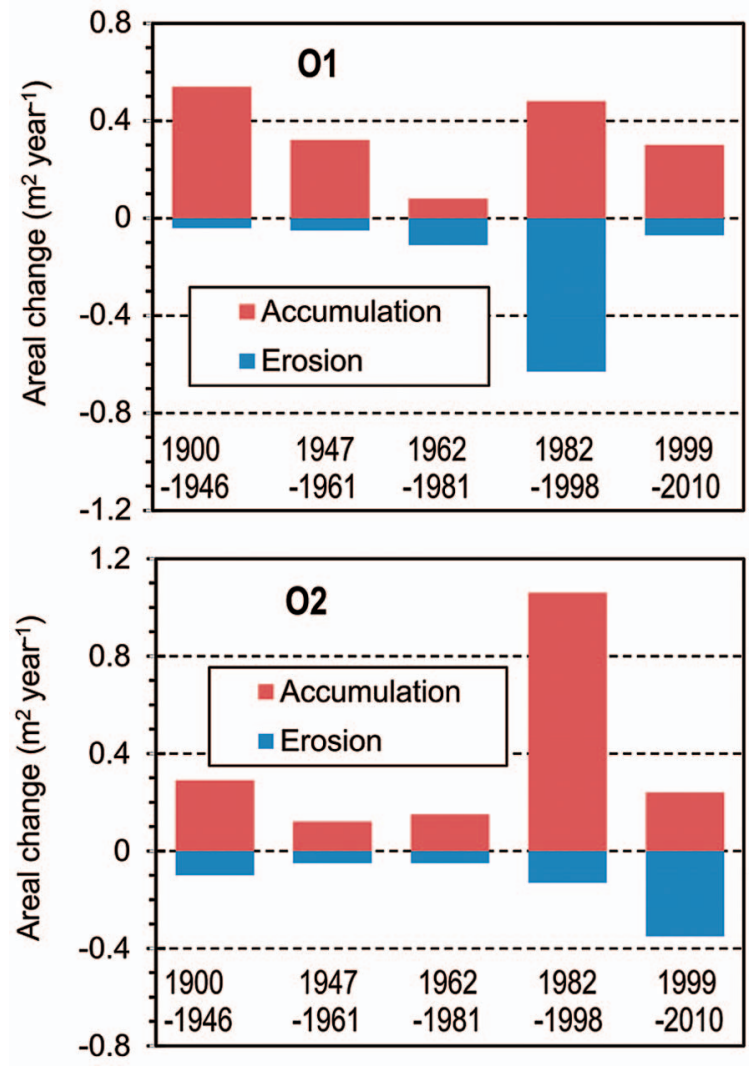

Fig. 10. Average areal changes (accumulation and erosion per one shoreline meter and year) in two study sites (01 and 02) in different periods.

beach ridges on profile 8) are evidence of dominant cross-shore transport. Many profiles on the southern Osmussaar coast show curious rhythmic patterns from the past (Fig. 11; see also Pruszak et al., 2008). Profile no. 9 on the NE coast of the Storhamne Bay shows 1-2 $\mathrm{m}^{3}$ accumulation per shoreline meter. Most of the new beach ridges are approximately 1 meter high, therefore it can be concluded that the rate of accumulation from 2011 September to 2012 November is roughly the same as it has been during the last decade.

Profile no. 11 indicates that the shoreline has receded landward up to 5 meters on the SE coast. This location is exposed to $\mathrm{N}$ and NE stormwaves. A decrease in the storm parameters from these directions has lead to slower rates of change. Sediments eroded from the eastern coast of Osmussaar are transported around the SE tip of the island and accumulated on the southern coast and 


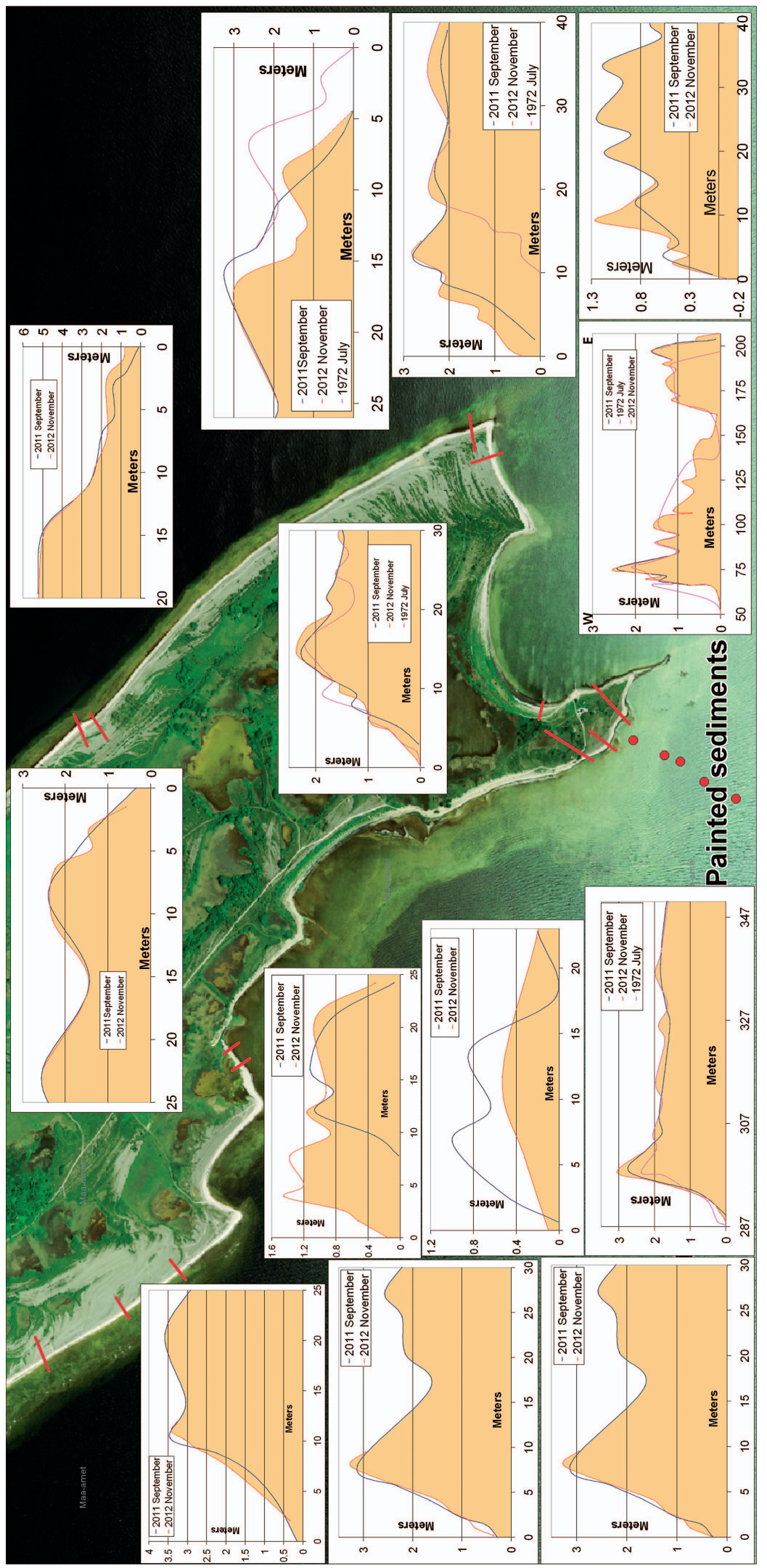

within Storhamne Bay (profiles no. 8 and 10).

All the remaining profiles were measured only twice (in 2011 and 2012). There were no major changes on profiles no. 1, 2, 3, 12 and 13. However, we can still observe that the conditions during the winter of 2011/12 have been rough enough to deposit some fresh sediment on top of the highest new beach ridges, up to 3.5 meters above mean sea level. Probably those conditions did not last long as there were no major changes on the lower parts of those profiles. Greater changes took place on the locations of profiles no. 4 and 5, where new spit increments started to grow and the distal part of the spit has been over-washed and levelled. The shoreline has advanced around 8 meters to the sea there. The existence of the over-wash at profile 5 confirms prior observations that salty water can occasionally flow into the coastal lakes under certain circumstances.

\subsection{Results of the tests with painted sediments}

The painted sediment piles were completely dispersed at depths from 2.5 to $4 \mathrm{~m}$, but remained nearly intact shoreward during the first 
two months of the experiment (Fig. 12). There were no strong storms during the period. More or less active erosion takes place over that steeper section of the underwater limestone bench (Fig. 13), which starts from $2.5 \mathrm{~m}$ isobath and where storm-waves typically break and dissipate. Above the broad and relatively shallow (1-3 $\mathrm{m}$ ) bench incident waves lose their energy and local wave heights are constrained by the shallow conditions.

One hour sustained wind speed reached $13 \mathrm{~m}$ $\mathrm{s}^{-1}$ during the first study period with the painted sediments (Fig. 4A). The measured $\mathrm{Hs}$ attained 2 $\mathrm{m}$ in the $11 \mathrm{~m}$ deep Sundgrund location (Fig. 4D). The sea-level remained close to the Kronstadt zero during the whole study period. Thus, waves of moderate storms in mean sea level conditions were capable of moving sediment fractions with a diameter of $1-10 \mathrm{~cm}$ shoreward if the depth exceeded 2 meters. Accumulation in the described conditions occurs at a depth of about $2 \mathrm{~m}$, where

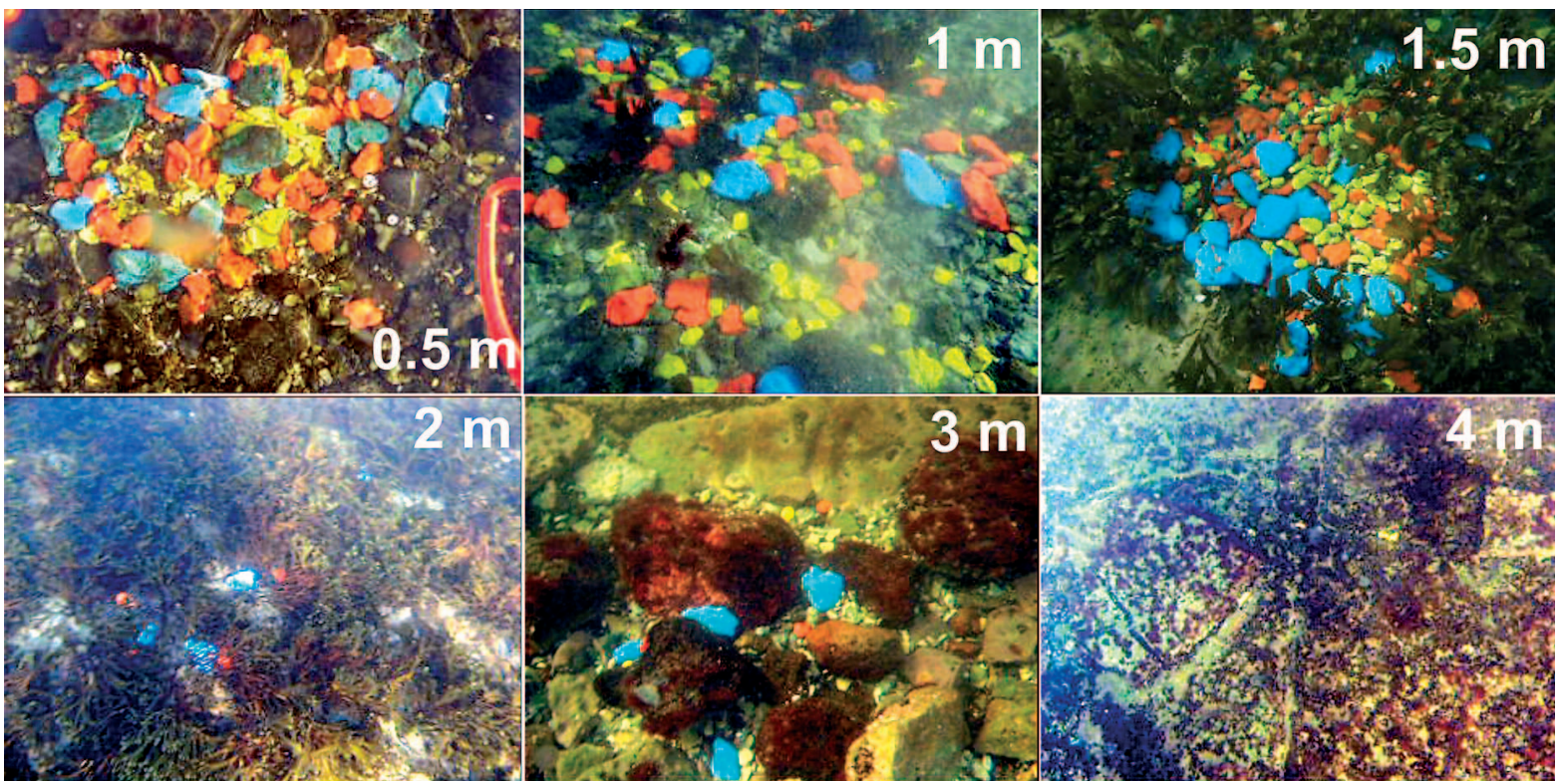

Fig. 12. The painted sediment piles during the first revisit in November 2011; see also Fig. 13. (underwater photos by H.Tõnisson).

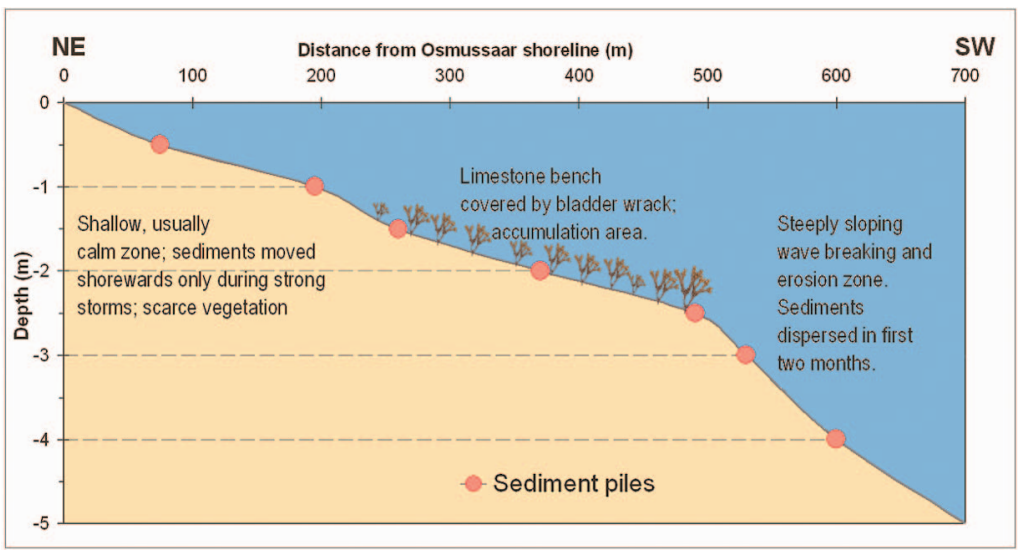

Fig. 13. Sea-bottom profile, the locations of painted sediments and description of changes. 
the angle of sea-bottom slope decreases and swash is unable to shift the sediment further.

Re-visiting the site for a second time in November 2012 revealed that the sediments at depths from 1.5 to 2.0 meters were still nearly intact. Sediment piles at $1 \mathrm{~m}$ and $0.5 \mathrm{~m}$ depths were completely dispersed. The smallest fractions from a 0.5 meter depth were found as far as 28 meters shoreward while the sediments from $1 \mathrm{~m}$ depth were found up to 16 meters shoreward from their original location. All the sediments were moved in an E or NE direction. Such significant changes were probably caused by strong storms that occurred from the end of November 2011 until the beginning of January 2012 (Fig. 4). According to the data from the Pakri station, maximum wind speed reached 21 $\mathrm{m} \mathrm{s}^{-1}$, thereby exceeding the $15 \mathrm{~m} \mathrm{~s}^{-1}$ "storm" limit by a third. Maximum sea-level reached nearly 1.2 meters (at Ristna) and significant wave heights (at Sundgrund) combined with sea-level reached 4.3 meters (Fig. 4).

The area between the depth of 2.5 meters and 1.5 meters was vegetated by bladderwrack (Fucus vesiculosus), which serves as another indicator of relatively low wave energy above the bench. We may assume that most of the waves in normal sea-level conditions break in depths of more than 2.5 meters, and the sediments eroded from the deeper sea are accumulated there as small submerged ridges that protect bottom vegetation. On the other hand, vegetation prevents shoreward movement of the sediments as well. In higher sea-level conditions (e.g., 1.2 meters, as in winter 2012), a secondary wave breaking zone may form, which transports sediments with the diameter of $1-10 \mathrm{~cm}$ from a depth of $1 \mathrm{~m}$ shoreward. Hence, most of the sediments accumulated on the beach ridges on the west coast of Osmussaar have been eroded from the cliff or nearshore sea bottom up to 1 meter depth. The deposits eroded from the deeper parts and accumulated in the zone of the bladderwrack may reach the shore only during the most extreme storms, such as in January 2005, when the sea-level occasionally reached 2 meters above mean sea-level. However, such events have occurred only twice or so in a century (Suursaar \& Sooäär, 2007).

\subsection{Future outlook and the climate change}

Climate change in the Baltic Sea area mainly manifests as winter-time warming, but also as sea level rise and increase in local storminess in winter months (Jaagus et al., 2008). Although the global sea level rise is projected to accelerate in the $21^{\text {st }}$ century (Kont et al., 2007), the margin of uncertainty is still high. At present, the regional uplift in the Osmussaar area is nearly balanced out by the global sea level rise, and going forward projected increasing storminess and sea level acceleration will likely reduce the island's area. The coastal processes on the westerly exposed coasts remain active. The most likely scenario will be continuous erosion from the westerly exposed shores and accumulation on the southerly exposed shores.

\section{Conclusions}

Based on measurements of waves as wave model calibration data and wind inputs from Pakri and Lääne Nigula weather stations, long-term (19662011) hindcasts of waves for the Osmussaar nearshore zone were created and hydrodynamic forcings for coastal changes were studied. The growth of the island has practically stopped as the current global sea level rise nearly balances out the local post-glacial uplift and stormwaves re-shape the island. Storminess and high sea level events have increased on the windward, westerly exposed coast but probably decreased on the northerly and easterly exposed coasts. Wave climate has undergone some cyclical changes with the last high phase in the 1980s-1990s and probably starting again in 2010. The shore processes on the western coast of Osmussaar Island are continuously active. The limestone cliff is slowly retreating on the northwestern and northern side of the island and the shoreline is migrating seaward in the southern part as a result of the formation of beach ridges and spits. The most rapid changes have occurred during periods of increased cyclonic activity (i.e. in the 1980s-1990s). Compared to the period of 19601980 , the rate of coastal change has increased from 
$0.2 \mathrm{~m}^{2} \mathrm{y}^{-1}$ to $1.2 \mathrm{~m}^{2} \mathrm{y}^{-1}$ per shoreline meter. Since the beginning of the 1980s, erosion occurred even in the zone of former sediment transport. The rate of shore changes has somewhat decreased during the last decade. However, the current rate still exceeds the changes measured before the 1980s.

The experiment with painted sediments showed that the waves of moderate storms in mean sea level conditions moved fractions with a diameter of 1$10 \mathrm{~cm}$ shoreward in $2-5 \mathrm{~m}$ depth zone. Accumulation of such fractions occurs at a depth of $2 \mathrm{~m}$, where swash is unable to shift the sediment further along. Bottom vegetation might be one of the inhibiting factors. These deposits can get onto the shore only in case of extreme storms. The painted sediments were also dispersed at depths of 0.5 to 1 $\mathrm{m}$ during strong storms with the local sea-level rise exceeding $1 \mathrm{~m}$ due to storm surges. A secondary wave dissipation zone might have appeared here due to the elevated sea-level. The results obtained helped us determine the feeding areas of beach ridges. The direction, velocity and extent of sediment disposal need additional analysis. Also, the lower depth limit, where the sediments can be transported, has not yet been found.

\section{Acknowledgements}

The study was supported by the Estonian Science Foundation grants No. 8549, 8980 and 9191, target financed project SF0180104s08 and the EstKliima project of the European Regional Fund programme No. 3.2.0802.11-0043. The authors are also grateful to Mrs. Kadri Vilumaa and Dr. Egert Vandel who assisted in the field work at Osmussaar, and to Dean Adam Willis for his assistance in providing English language editorial suggestions.

\section{References}

Church, J.A. \& White, N.J. 2006. A 20th century acceleration in global sea level rise. Geophysical Research Letters 33, L01602.

Church, J.A. \& White, N.J. 2011. Sea-level rise from the late 19 th to the early 21 st century. Surveys in Geophysics 32, 585-602.

Dailidiene, I., Davuliene, L., Tilickis, B., Stankevičius, A. \& Myrberg, K. 2006. Sea level variability at the Lthuanian coast of the Baltic Sea. Boreal Environment Research 11, 109-121.
Ekman, M. 1999. Climate changes detected through the world's longest sea level series. Global and Planetary Change 21, 215-224.

Jaagus, J. \& Kull, A. 2011. Changes in surface wind directions in Estonia during 1966-2008 and their relationships with large-scale atmospheric circulation. Estonian Journal of Earth Sciences 60, 220-231.

Jaagus, J., Post, P. \& Tomingas, O. 2008. Changes in storminess on the western coast of Estonia in relation to large-scale atmospheric circulation. Climate Research 36, 29-40.

Johansson, M., Boman, H., Kahma, K.K. \& Launiainen, J. 2001. Trends in sea level variability in the Baltic Sea. Boreal Environment Research 6, 159-179.

Keevallik, S. \& Soomere, T. 2009. Seasonal and diurnal variations of wind parameters at Pakri. Estonian Journal of Engineering 15, 227-239.

Kont, A., Endjärv, E., Jaagus, J., Lode, E., Orviku, K., Ratas, U., Rivis, R., Suursaar, Ü. \& Tônisson, H. 2007. Impact of climate change on Estonian coastal and inland wetlands - a summary with new results. Boreal Environment Research 12, 653-671.

Lambeck, K., Smither, C. \& Ekman, M. 1998. Tests of glacial rebound models for Fennoscandinavia based on instrumented sea- and lake-level records. Geophysical Journal International 135, 375-378.

Massel, S.R. 2010. Surface waves in deep and shallow waters. Oceanologia 52, 5-52.

Mellgren, J.I.S., Schmitz, B., Ainsaar, L., Kirsimäe, K. \& Eriksson, M.E. 2012. Conodont dating of the Middle Ordovician breccia cap-rock limestone on Osmussaar Island, northwestern Estonia. Estonian Journal of Earth Sciences 61, 133-148.

Orviku, K. 1979. On investigations of onshore movement of gravel beach sediments. Investigations evolutions of topography of seashores. Moskva. Nauka. pp 65-67. (in Russian)

Orviku, K., Suursaar, Ü., Tônisson, H., Kullas, T., Rivis, R. \& Kont, A. 2009. Coastal changes in Saaremaa Island, Estonia, caused by winter storms in 1999, 2001, 2005 and 2007. Journal of Coastal Research, Special Issue 56, 1651-1655.

Otsmann, M., Astok, V. \& Suursaar, Ü. 1997. A model for water exchange between the Baltic Sea and the Gulf of Riga. Nordic Hydrology 28, 351-364.

Peil, T. 1999. Settlement history and cultural landscapes on Osmussaar. Estonia Maritima 4, 5-38.

Pruszak, Z., Rozynski, G. \& Szmytkiewicz, P. 2008. Megascale rhythmic shoreline forms on a beach with multiple bars. Oceanologia 50, 183-203.

Soomere, T., Myrberg, K., Leppäranta, M. \& Nekrasov, A. 2008. The progress in knowledge of physical oceanography of the Gulf of Finland: a review for 1997-2007. Oceanologia 50, 287-362.

Suuroja, K., Saadre, T. \& Kask, J. 1999. Geology of Osmussaar 
Island. Estonia Maritima 4, 39-63.

Suuroja, K. \& Suuroja, S., 1999. Neugrund structure - a submarine meteorite crater at the entrance to the Gulf of Finland. Estonia Maritima 4, 161-189.

Suuroja, K. \& Suuroja, S. 2000. Neugrund structure - the newly discovered submarine early Cambrian impact crater. Lecture Notes in Earth Sciences 91, 389-416.

Suursaar, Ü., Szava-Kovats, R. \& Tônisson, H. 2011. Wave climate and coastal processes in the Osmussaar Neugrund region, Baltic Sea. Coastal processes II. Book Series: WIT Transactions on Ecology and the Environment, 149, WIT Press: Southampton, Boston, p. 99-110.

Suursaar, Ü. 2010. Waves, currents and sea level variations along the Letipea - Sillamäe coastal section of the southern Gulf of Finland. Oceanologia 52, 391-416.

Suursaar, Ü. 2013. Locally calibrated wave hindcasts in the Estonian coastal sea in 1966-2011. Estonian Journal of Earth Sciences 62, 42-56.

Suursaar, Ü., Jaagus, J., Kont, A., Rivis, R. \& Tõnisson, H. 2008. Field observations on hydrodynamic and coastal geomorphic processes off Harilaid Peninsula (Baltic Sea) in winter and spring 2006-2007. Estuarine Coastal and Shelf Science 80, 31-41.

Suursaar, Ü. \& Kullas, T. 2009. Decadal variations in wave heights off Kelba, Saaremaa Island, and their relationships with changes in wind climate. Oceanologia 51, 39-61.

Suursaar, Ü., Kullas, T. \& Aps, R. 2012. Currents and waves in the northern Gulf of Riga: measurement and long-term hindcast. Oceanologia 54, 421-447.

Suursaar, Ü., Kullas, T., Otsmann, M., Saaremäe, I., Kuik, J. \& Merilain, M. 2006. Cyclone Gudrun in January 2005 and modelling its hydrodynamic consequences in the Estonian coastal waters. Boreal Environment Research 11, 143-159.
Suursaar, Ü. \& Sooäär, J. 2007. Decadal variations in mean and extreme sea level values along the Estonian coast of the Baltic Sea. Tellus A 59, 249-260.

Zaitseva-Pärnaste, I., Suursaar, Ü., Kullas, T., Lapimaa S. \& Soomere, T. 2009. Seasonal and long-term variations of wave conditions in the northern Baltic Sea. Journal of Coastal Research, Special Issue 56, 277-281.

Tõnisson, H., Suursaar, Ü. \& Kont, A. 2012. Maps, aerial photographs, orthophotos and GPS data as a source of information to determine shoreline changes, coastal geomorphic processes and their relation to hydrodynamic conditions on Osmussaar Island, Baltic Sea. IEEE International Geoscience and Remote Sensing Symposium (IGARSS), 22-27 July 2012, Munich, Germany. IEEE, p. 2657-2660.

Tônisson, H., Suursaar, Ü., Orviku, K., Jaagus, J., Kont, A., Willis, D.A. \& Rivis, R. 2011. Changes in coastal processes in relation to changes in large-scale atmospheric circulation, wave parameters and sea levels in Estonia. Journal of Coastal Research, Special Issue 64, 701-705.

Tõnisson, H., Orviku, K., Jaagus, J., Suursaar, Ü., Kont, A. \& Rivis, R. 2008. Coastal Damages on Saaremaa Island, Estonia, Caused by the Extreme Storm and Flooding on January 9, 2005. Journal of Coastal Research 24, 602614.

USACE 1984. U.S. Army Coastal Engineering Research Center, Shore Protection Manual, Vol.1, Third Ed., U.S. Govt. Printing Office, Washington D.C., 719 p.

Vallner, L., Sildvee, H. \& Torim, A. 1988. Recent crustal movements in Estonia. Journal of Geodynamics 9, 215223.

Öpik, A. 1927. Die Inseln Odensholm und Rogö. Ein beitrag zur Geologie von NW-Estland. Acta Univ. Tartu, A XVII, $1-69$. 